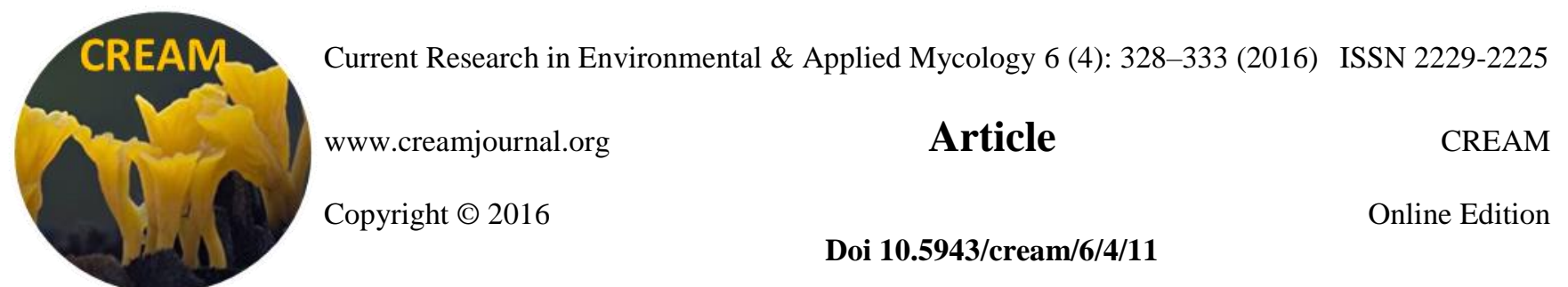

\title{
Lichens of the Western Ghats new to India
}

\author{
Joshi Santosh $^{1^{*}}$ and Upreti DK ${ }^{2}$ \\ ${ }^{1,2}$ Lichenology laboratory, CSIR-National Botanical Research Institute, Rana Pratap Marg, Lucknow (UP)-226001, India
}

Joshi S, Upreti DK 2016 - Lichens of the Western Ghats new to India. Current Research in Environmental \& Applied Mycology 6 (4): 328-333, Doi 10.5943/cream/6/4/11

\begin{abstract}
Ten new records of lichens are described from the Nilgiri Hills, Silent Valley National Park and the area around Mahabaleshwar. A brief description of each species is provided with ecology and distribution, and well supported by illustrations.
\end{abstract}

Key words - corticolous - Kerala - Maharashtra - records - saxicolous -Tamil Nadu.

\section{Introduction}

India is the country of large landscape with several topological variations, which provide countless varieties of niches and the organisms inhabiting them. The Western Ghats in India extends from Tapti valley in the north of Gujarat to Kanyakumari of Tamil Nadu in the south. It is one of the 13 mega biodiversity hotspots of the world (Myers et al. 2000). A long stretch of the Western Ghats covers a range of palaeotropic vegetation derived from original Gondawana land and includes evergreen, tropical deciduous, scrub, montane, subtropical temperate forests and grasslands (Nayar 1982). It exhibits the maximum species richness with more endemism than other phytogeographical regions of India. Apart from other organisms, lichens in the Western Ghats are significant biotic component and have been treated in different studies (Awasthi 1988, 1991, 2007, Singh 1976, Nayaka \& Upreti 2006, Upreti \& Divakar 2010, Pandit \& Sharma 2012). In an ongoing course of work, lichens of the Western Ghats are catalogued including a bulk of material collected in the recent past and the lichens preserved in the herbarium long decades before. Based on which several noteworthy species were identified and recorded new for the country and many others for the Western Ghats as well. The present work describes ten new records of lichens collected from the Nilgiris Hills, Silent Valley National Park and around Mahabaleshwar in the Western Ghats.

\section{Materials \& Methods}

The examined lichen material was preserved in the herbarium of CSIR-National Botanical Research Institute, Lucknow (LWG). The morphological and anatomical details were extracted using binocular and compound microscopes. The chemical analysis was performed using Orange et al. (2001). Thin Layer Chromatography was done using solvent system A. All illustrations were prepared in Corel Draw (version 12).

Acanthothecis gracilis Staiger \& Kalb, Mycotaxon 73: 99. 1999.

Fig. 1

Thallus corticolous, crustose, greenish-grey to grey, continuous, thin, dull, corticate; ascomata apothecioid, round to shortly lirellate, 1-2 mm long, fissured, lacerate, protruding out of the bark, white, delicate; disc slightly open, indistinctly white pruinose; hymenium hyaline, clear, 100-150 $\mu \mathrm{m}$ 
high, periphysoids warty, developing at inner side of the margin, 20-35 $\mu \mathrm{m}$ long; ascus 8-spored, $143-$ $147 \times 10-12 \mu \mathrm{m}$, ascospores submuriform to muriform, $25-35 \times 8-10 \mu \mathrm{m}, \mathrm{I}-$.

Chemistry - Norstictic acid.

Known distribution - The species is common in Western Ghats, and was found growing with other graphidoid taxa on bark of tree trunk and twigs in tropical rain forests of the Nilgiri Biosphere Reserve. World-wide it has distribution in Australia and Northern America (Staiger \& Kalb 1999).

Material examined - India, Tamil Nadu, The Nilgiris, Doddabetta, alt. 248 m, on bark, 17 February 2012, P. Shukla, K. Ingle \& Logesh A. R. s.n. (LWG); Kerala, Palakkad district, Silent Valley National Park, on way to Poochipara, alt. 1090 m, on bark, 02 April 2015, S. Joshi, H. Rai \& Logesh A. R. 15-026047(LWG).

Notes - The species resembles Acanthothecis socotrina (Müll. Arg.) Staiger \& Kalb in a thallus containing norstictic acid, which differs in having 2-6-spored asci and slightly larger ascospores, 28$42 \times 10-15 \mu \mathrm{m}$ (Staiger 2002). The reddish ascocarps of the examined specimen give appearance of red pigmentation, which however is due to the higher concentration of norstictic acid.

Anisomeridium glaucescens (Müll. Arg.) R. C. Harris, More Florida Lichens, Incl. 10 Cent Tour Pyrenol. (New York): 146. 1995.

Fig. 2

Thallus corticolous, crustose, olive green to green, thin, smooth, glossy, continuous, corticate, UV-; apothecia perithecioid, $0.2-0.4 \mathrm{~mm}$ in diam., \pm immersed, black, solitary, ostiole lateral; hymenium hyaline, clear, 150-200 $\mu \mathrm{m}$; ascus 8-spored, 165-175 $\times 13-17 \mu \mathrm{m}$, ascospores fusiform, smooth walled, transversely 1-3-septate, 28-32 × 8-9 $\mu \mathrm{m}$.

Chemistry - No lichen substances.

Known distribution - The species is collected in southernmost part of Western Ghats, where it was growing along with some graphidoid taxa. It has previously been described from Cuba (Harris 1995).

Material examined - India, Kerala, Thiruvananthapuram district, Karyavattom, Kerala University campus, alt. 40 m, on bark, 08 August 2013, Logesh A. R. \& R. Ravinesh s.n. (LWG).

Notes - Anisomeridium immersum (Makhija \& Patwardhan) R. C. Harris is close to A. glaucescens in most of the taxonomical characters, but differs in having larger ascospores, $>50 \mu \mathrm{m}$.

Graphis copelandii (Vain.) P. M. Jorg, Li Ann. Acad. Sci. fenn., Ser. A 15(6): 207. 192.

Fig. 3

Thallus corticolous, crustose, greyish-green to brownish-green, thick, dull, smooth, corticate, $\leq 300 \mu \mathrm{m}$ thick; ascomata lirellate, lirellae immersed to erumpent with lateral thalline margin, $\leq 5 \mathrm{~mm}$ long; labia entire; disc concealed; proper exciple laterally carbonized; hymenium hyaline and clear, 150-200 $\mu \mathrm{m}$ high; ascus 1-2-spored; ascospores hyaline, muriform, 60-90 × 18-22 $\mu \mathrm{m}$, I+ violet.

Chemistry - Norstictic acid.

Known distribution - The species was collected from the smooth bark of Cocos nucifera, where it was growing luxuriantly in association with some sorediate lichen taxa. Globally, it has eastern palaeotropical distribution (Lücking et al. 2009).

Material examined - India, Karnataka, Manglore, on bark, 04 May 1979, D. D. Awasthi, D. K. Upreti \& U. Mishra 79-684 (LWG-LWU).

Notes - The species is similar to Graphis subserpentina Nyl. in lirellae anatomy and a thallus producing norstictic acid, but the latter species contains larger ascospores $(\leq 150 \mu \mathrm{m}$ long $)$.

Graphis ferruginea Vain., Ann. Acad. Sci. fenn., Ser. A 15(6): 257. 1921.

Fig. 4

Thallus corticolous, crustose, greenish-grey to pale grey, uneven due to bark texture, thick, corticate; ascomata lirellate, lirellae 5-10 mm long, richly branched, prominent, sinuous, with lateral thalline margin, orange to cinnabar red pruina covering the labia; hymenium hyaline, inspersed, 100 $120 \mu \mathrm{m}$ high; ascus 8-spored, 100-110 × 10-12 $\mu \mathrm{m}$; ascospores hyaline, muriform, $4 \times 1-2$ locular, 22-25 × 8-12 $\mu \mathrm{m}$, I+ violet.

Chemistry - Salazinic acid. 
Known distribution - The species was collected from the reserve forest of Avalanche, where it was growing on tree bark in shady places. It has distribution in eastern palaeotropics (Lücking et al. 2009).

Material examined - India, Tamil Nadu, The Nilgiris, Avalanche, Hatchery Shola, alt. ca 1500 m, on bark, 23 December 1971, K. P. Singh 71-627 (LWG-LWU).

Notes - The species is distinct in producing pigmented (red) pruina on labia and salazinic acid. The neotropical Graphis chrysocarpa (Raddi) Spreng. is comparable, but it lacks lichen substances, and has much larger ascospores.

Lecanographa follmannii (C. W. Dodge) Egea \& Torrente, Biblioth. Lichenol. 54: 133. $1994 . \quad$ Fig. 5

Thallus corticolous, crustose, whitish-grey to greenish-grey, continuous; ascomata lirellate, lirellae simple, short, bi-furcate, sessile, $\leq 1 \mathrm{~mm}$ long, disc exposed, dark brown; proper exciple laterally carbonized, 30-40 $\mu \mathrm{m}$ thick, epihymenium dark brown, 15-20 $\mu \mathrm{m}$ high, hymenium hyaline, matrix gelatinous, $\leq 50 \mu \mathrm{m}$ high, hypothecium brown, 30-40 $\mu \mathrm{m}$ high; ascus 8-spored, ascospores sole shaped, hyaline to brown, transversely 3-4-septate, $14-17 \times 3-4 \mu \mathrm{m}$.

Chemistry - No lichen substances, except unknown pink spot at $\mathrm{R} f$ value 5-6.

Known distribution - The species was collected at higher altitudes of Nilgiri hills from bark of trees having wide girth, where it was growing along with other members of Arthonials. Previously, it was described from Chile (Egea \& Torrente 1994).

Material examined - India, Tamil Nadu, The Nilgiris, $1 \mathrm{~km}$ before Love Dale railway station, towards Kundah, alt. 2195 m, on bark, 03 March 2014, S. Joshi \& Logesh A. R. 14-020953 (LWG).

Notes - This taxon apparently resembles lirellate species of Arthonia, which however differs in producing typical Arthonia-type ascus. Lecanographa lyncea (Sm.) Egea \& Torrente is nearer to $L$. follmannii, but produces comparatively larger ascospores.

Porina farinosa C. Knight, Syn. Queensl. Fl. 1(Suppl.): 73. 1886.

Fig. 6

Thallus corticolous, crustose, pale greyish-brown, continuous to rimose, smooth, coarsely verrucose, corticate; prothallus grey to brown; perithecia verrucose, convex, plane to rounded, 0.4-0.7 mm diam; involucrellum colourless, 50-75 $\mu \mathrm{m}$ thick; hymenium inspersed with oil droplets; asci 8spored, $210-410 \times 35-65 \mu \mathrm{m}$; ascospores narrowly to broadly ellipsoid or fusiform, muriform (15-30 $\times 2-4), 56-103 \times 20-40 \mu \mathrm{m}$.

Chemistry - No lichen substances.

Known distribution - The species was found growing on thick barked trees at higher elevations in association with parmelioid and cyanoid lichen groups. It has pantropical distribution (McCarthy 2009).

Material examined - India, Tamil Nadu, The Nilgiris, enroute to Avalanche, Yellakandy area, alt. 2122 m, on bark, 03 April 2014, S. Joshi \& Logesh A. R. 14-022150 (LWG).

Notes - Porina exocha (Nyl.) PM McCarthy being similar to Porina farinosa in most of the taxonomical characteristics, but has slightly larger perithecia $(\leq 1 \mathrm{~mm})$ and ascospores usually with a hyaline apical cap.

Porina nigrofusca Müll. Arg., Flora, Regensburg 66(20): 322. 1883.

Fig. 7

Thallus saxicolous, crustose, epilithic, well developed, smooth, continuous, dark grey, olive green to greenish-grey, corticate; ascomata perithecioid, perithecia emergent, solitary, black, 0.2-0.4 $\mathrm{mm}$ in diam., ostiole inconspicuous; involucrellum dimidiate, apically carbonized, hymenium hyaline, containing algae, 196-200 $\mu \mathrm{m}$ high; ascus 8-spored, $\leq 150 \times 10-12 \mu \mathrm{m}$, ascospores hyaline, fusiform, transversely 3-septate, 30-33 × 4-5 $\mu \mathrm{m}$.

Chemistry - No lichen substances, except unknown yellow spots at $R f$ value $3 \& 6$.

Known distribution - The species was found growing in a long stretch of elevation with other common crustose lichens of the area on wet surfaces of rocks. It is known from Brazil and Australia (McCarthy 2009). 

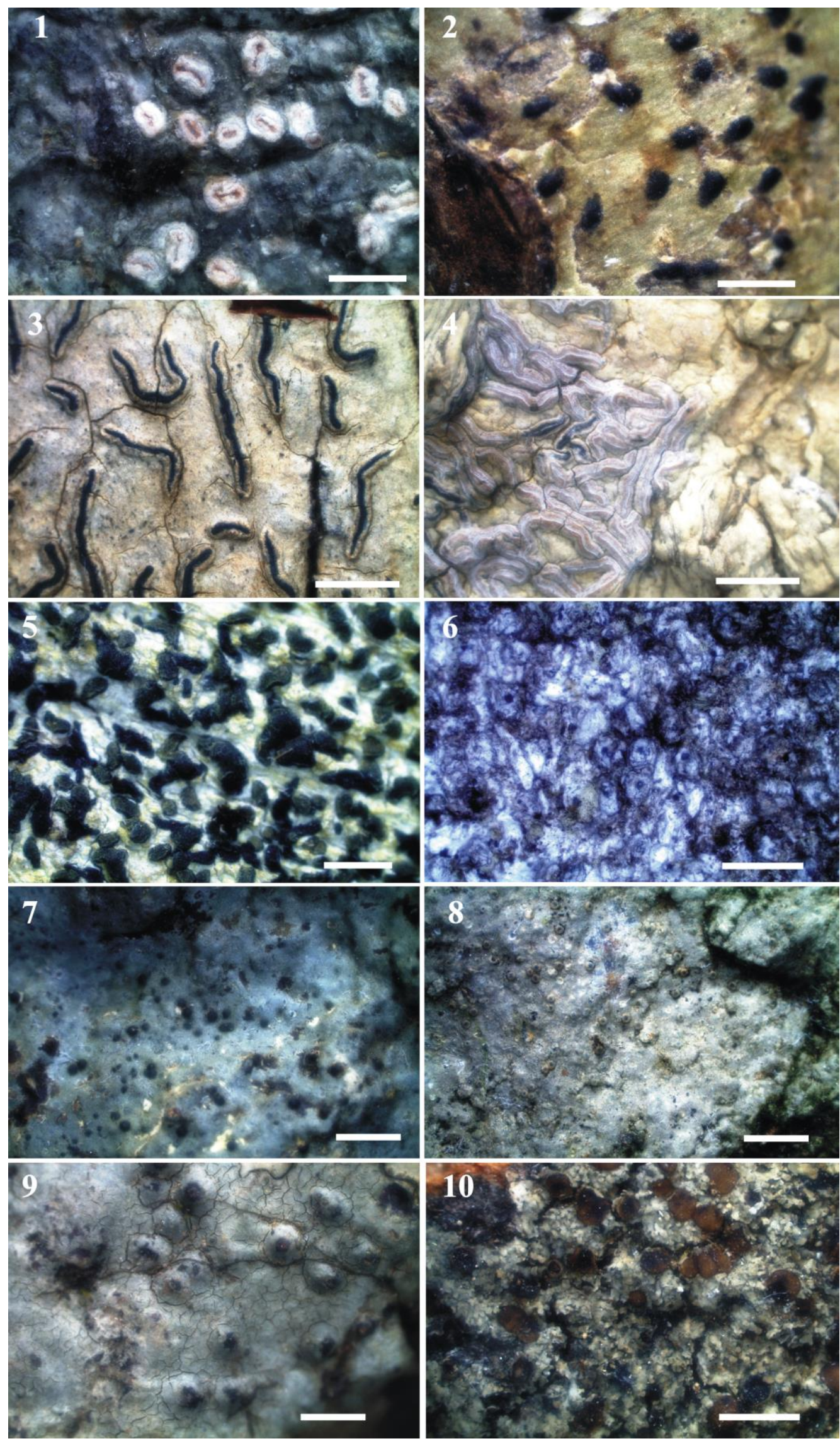

Figs 1-10 - New records of lichens. 1. Acanthothecis gracilis. 2. Anisomeridium glaucescens. 3. Graphis copelandii. 4. G. ferruginea. 5. Lecanographa follmannii. 6. Porina farinosa. 7. Porina nigrofusca. 8. Porina tasmanica, 9. Staurothele verruculosa, 10. Vahliella saubinetii. - Bars $=$ $1,3,4,6,7,8=2 \mathrm{~mm} .2,10=0.5 \mathrm{~mm} .5,9=1 \mathrm{~mm}$. 
Material examined - India, Maharashtra, Satara, near Ghatmatha, alt. $631 \mathrm{~m}$, on rock, 24 March 2010, R. Bajpai 10-013315 (LWG); Mahabaleshwar, Wilson Point, alt. 1470 m, on exposed rock, 26 March 2010, R. Bajpai 10-013980 (LWG).

Notes - Porina chloroticula P. M. McCarthy is close to P. nigrofusca in having an involucrellum enclosing algal cells, 3-septate ascospores and a saxicolous habit, but differs in producing slightly smaller perithecia and a filmy thallus.

Porina tasmanica P. M. McCarthy, Biblioth. Lichenol. 52: 105. 1993.

Fig. 8

Thallus saxicolous, crustose, epilithic, olive green to dark green, greyish-green, thin, corticate; ascomata perithecioid, perithecia sessile, $0.1-0.3 \mathrm{~mm}$ in diam, solitary, concolorous with thallus or reddish brown, ostiole apical; involucrellum dimidiate, black to internally orange-brown hymenium hyaline, containing algal cells; ascus 8-spored, 70-80 $\times 8-10 \mu \mathrm{m}$, ascospores, fusiform, hyaline, transversely 3 -septate $18-22 \times 3-5 \mu \mathrm{m}$.

Chemistry - No lichen substances, except unknown yellow spot at $\mathrm{R} f$ value 7 .

Known distribution - The species was recorded in shaded areas of semi-exposed forests in the Nilgiri Hills, where it was growing solely with no other rock inhabiting lichens. It was previously known from Tasmania (McCarthy 2009).

Material examined - India, Tamil Nadu, The Nilgiris, Kallar foot hills, alt. 439-488 m, on rocks, 02 March 2014, S. Joshi \& Logesh A. R. 14-024082 (LWG).

Notes - It differs from Porina nigrofusca only in having reddish-brown perithecia. Morphoanatomically similar Porina hyperleptalea P.M. McCarthy \& Kantvilas differs only in having slightly large perithecia.

Staurothele verruculosa J. W. Thompson, Bryologist 94(4): 364. 364.

Fig. 9

Thallus saxicolous, crustose, epilithic, olive-green, greyish-green to dark green, thin, dull, smooth, corticate; ascomata perithecioid, $\leq 1 \mathrm{~mm}$ in diam., ostiole apical, black; involucrellum reddish black; proper exciple, reddish brown; hymenium hyaline, $\leq 200 \mu \mathrm{m}$ high, containing cylindrical algal cells; ascus 8-spored, $125-130 \times 25-35 \mu \mathrm{m}$, ascospores ellipsoidal, hyaline, muriform $(5-10 \times 2-3$ septate), 30-35 × 10-15 $\mu \mathrm{m}$.

Chemistry - No lichen substances.

Known distribution - The species was growing in patches on uneven and wet rock surfaces, and collected from central region of the Western Ghats. It has a world-wide distribution in central Arizona (Nash et al. 2001).

Material examined - India, Maharashtra, Satara, Mahabaleshwar, Medha road, Graveyard area, on rock, 26 March 2011, R. Bajpai 11-015519 (LWG).

Notes - The genus Staurothele was previously recorded for three species, viz., Staurothele clopima (Wahlenb.) Th. Fr., Staurothele drummandii (Tuck.) Tuck. and Staurothele fissa (Taylor) Zwackh, which are distinguished from $S$. verruculosa in producing 2-spored asci.

Vahliella saubinetii (Mont.) P. M. Jфrg, Lichenologist 40(3): 224. 2008.

Fig. 10

Thallus corticolous, squamulose, composed of small squamules $\leq 1.5 \mathrm{~mm}$ wide, usually overlapping forming brownish to bluish-grey crust; photobiont layer consisting of clumps of Nostoc; ascomata apothecioid, $\leq 0.5 \mathrm{~mm}$ in diam., numerous, light brown, disc plane to convex, thalline exciple absent, true exciple persistent, concolorous with disc; hymenium hyaline, clear, 100-120 $\mu \mathrm{m}$ high; asci 8-spored, 50-80 × 15-20 $\mu \mathrm{m}$, ascospores hyaline, simple, 10-15 ×5-6 $\mu \mathrm{m}$.

Chemistry - No lichen substances.

Known distribution - The species prefers to grow in cold-temperate climate. In India it was recorded at higher altitude rain forests of Western Ghats, where it was growing in underside of moist and thick branches of trees in shaded areas. Globally, it has been recorded from America, Europe and Mediterranean regions (J $\phi$ rgensen 2000).

Specimen examined - India, Tamil Nadu, The Nilgiris, Korakundah, alt. 2305 m, on bark, 03 March 2014, S. Joshi \& Logesh A. R. 14-024094 (LWG). 
Notes - The genus Vahliella was extracted from the subgenus micropannaria in Fuscopannaria recently by J $\phi$ rgensen (2008), based on characters: a squamulose, mainly greyish to brownish thallus; sessile apothecia with variable thalline exciple (sometimes lacking) and proper exciple; a hemi-amyloid hymenium, unbranched, septate paraphyses with pigmented apices; 8-spored asci with sheet-like apical structures that are persistently I+ blue-green; and simple, ellipsoid ascospores, lacking epispore but often with internal oil droplets. Phylogenetically well separated genus is mostly restricted to coldtemperate areas in contrast to the species of Fuscopannaria. Members of Vahliella have been reported previously from high altitudes of Nilgiris under pannariaceous lichens.

\section{Acknowledgements}

This work was financed by DST-SERB project no. SERB-DST (DST no. SERB/LS297/2013). Authors thank Director, CSIR-NBRI, Lucknow, for providing lab facilities. Santosh Joshi is highly indebted to lichen collectors for their co-operation during field trips to accomplish the study.

\section{References}

Awasthi DD. 1988 - A key to the macrolichens of India, Nepal and Sri Lanka. Bibliotheca Lichenologica, 40, 1-337.

Awasthi DD. 1991 - A key to microlichens of India, Nepal and Sri Lanka. Bibliotheca Lichenologica 40, 1-337.

Awasthi DD. 2007 - A Compendium of the Macrolichens from India, Nepal and Sri Lanka. Bishen Singh Mahendra Pal Singh, Dehra Dun, India. p. 1-580.

Egea JM, Torrente P. 1994 - "El generos de hongos liquenizados Lecanactis (Ascomycotina)". Bibliotheca Lichenologica (in Spanish). 54, 1-205.

Harris RD. 1995 - More Florida lichens, including the 10 cent tour of the pyrenolichens. p. 1-192.

Jørgensen PM. 2000 - Survey of the lichen family Pannariaceae on the American continent, north of Mexico. The Bryologist 103, 670-704.

Jørgensen PM. 2008 - Vahliella, a new lichen genus. Lichenologist 40, 221-225.

Lücking R, Archer AW, Aptroot A. 2009 - A world-wide key to the genus Graphis (Ostropales: Graphidaceae). Lichenologist 41, 363-452.

McCarthy PM. 2009 - Porina; in: P.M. McCarthy (ed.). Flora of Australia. 58A, Lichens 3. Canberra: Australia Government Publishing Service. p. 106-153.

Myers N, Mittermeier RA, Mittermeier CG, da Fonseca, J. Kent GA. 2000 - Biodiversity hotspots for conservation priorities. Nature 403, 853-885.

Nash TH, Ryan BD, Gries C, Bungartz F. (eds.) 2001. - Lichen Flora of the Greater Sonoran Desert Region. Vol 1. Tempe, AZ.

Nayaka S, Upreti DK. 2006 - Status of Lichen Diversity in Western Ghats, India. Sahyadri E-News, Western Ghats Biodiversity Information System - Issue XVI.

Nayar MP. 1982 - Endemic flora of peninsular India and its significance. Bull. Bot. Surv. India. 22, $12-23$.

Orange A, James PW, White FJ. 2010 - Microchemical methods for the identification of lichens. British Lichen Society, London. p. 1-101.

Pandit G, Sharma B. 2012 - New records in the lichen family Lobariaceae from the Western Ghats of India. Mycosphere 3, 430-435.

Singh KP, Sinha GP. 1976 - Enumeration of macrolichens from Nilgiri hills, India. Geophytology 6, 27-34.

Staiger B. 2002 - Die Flechtenfamile Graphidaceae. Studien in Richtung einer natulicheren Gleiderung. Bibliotheca Lichenologica 85, 1-526.

Staiger B. Kalb K. 1999. - Acanthothecis and other graphidioid lichens with warty periphysoids or paraphysis-tips. Mycotaxon 73, 69-134.

Upreti D, Divakar PK. 2010 - A new species in the lichen genus Sticta (Schreb.) Ach. (Lobariaceae) from the Indian subcontinent. Nova Hedwigia 90, 251- 255. 